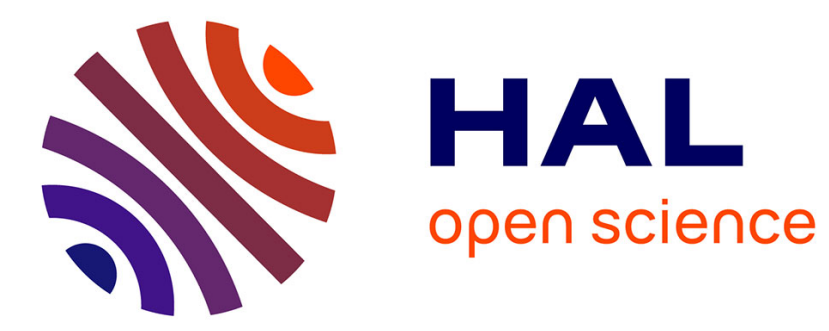

\title{
Effect of sward type on intake rate parameters during progressive defoliation by lambs \\ Gp Cosgrove, Rj Mitchell
}

\section{To cite this version:}

Gp Cosgrove, Rj Mitchell. Effect of sward type on intake rate parameters during progressive defoliation by lambs. Annales de zootechnie, 1995, 44 (Suppl1), pp.249-249. hal-00889408

\section{HAL Id: hal-00889408 \\ https://hal.science/hal-00889408}

Submitted on 1 Jan 1995

HAL is a multi-disciplinary open access archive for the deposit and dissemination of scientific research documents, whether they are published or not. The documents may come from teaching and research institutions in France or abroad, or from public or private research centers.
L'archive ouverte pluridisciplinaire HAL, est destinée au dépôt et à la diffusion de documents scientifiques de niveau recherche, publiés ou non, émanant des établissements d'enseignement et de recherche français ou étrangers, des laboratoires publics ou privés. 


\title{
Effect of sward type on intake rate parameters during progressive defoliation by lambs
}

\author{
GP Cosgrove, RJ Mitchell \\ AgResearch Sustainable Production Systems Division, Private Bag 11008, Palmerston North, New Zealand
}

As a canopy is grazed down progressive changes in the quality, composition, height and bulk density affect daily intake through rate of intake during grazing or grazing time each day. These changes constrain the modelling of daily intake on the basis of initial canopy structure and grazing duration. Definition of how contrasting canopy structures affect ingestion is necessary to optimise the balance between maintaining a high rate of intake and efficiently utilising the forage by grazing. The aim of this work was to characterise attributes of selected forage species that affect the rate of intake during progressive defoliation.

Eight-month-old lambs (40-50 kg liveweight), confined in metabolism crates, were offered trays of each of 6 plant species ; ryegrass (Lolium perenne), white clover (Trifolium repens) and plantain (Plantago lanceolata) representing prostrate grass, legume and herb species, respectively, and prairie grass (Bromus wildenowii), lucerne (Medicago sativa) and chicory (Chicorium intybus), representing erect grass, legume and herb species, respectively. Visual observation during grazing and detailed measurements on swards before and after each grazing interval were used to estimate biting rate, bite mass, and bite depth area and volume. This procedure was repeated as animals defoliated successive vertical strata, until canopies were $50 \mathrm{~mm}$ or less in height. Before grazing each stratum, canopies were trimmed to an even surface height based on depth of biting in the previous stratum. Results were analysed by ANOVA and meaned across strata for presentation.

For herb and legume species, intake rate was higher for prostrate examples, than for the erect examples. In contrast, intake rate of the erect grass was greater than that of the prostrate grass (plant form $\times$ type interaction, $P=0.0001$ ). Within the prostrate group, the higher intake rate of the legume and herb than of the grass, based on a greater bite mass, is consistent with a previous comparison of grasses and legumes (Gong et al, 1993, Proc XVII Intl Grassid Congr, 1, 726-728). However, within the erect group the similar intake rate of grass, herb and legume indicates that a general conclusion on the greater intake rate of legumes than that of grasses does not apply when contrasting plant types are compared. These data are based on the mean rate of intake for the entire defoliation, as compared with previous grass and legume comparisons based on the intake rate which animals are able to achieve from canopies at the start of defoliation (Gong et al, 1993).

To explain differences in animal performance across a range of plant species, based on ingestive behaviour, it is important to record the entire defoliation process, not just the high instantaneous values possible at the start of defoliation.

\begin{tabular}{|c|c|c|c|c|c|c|c|c|c|}
\hline \multirow[t]{3}{*}{$---\quad-$} & \multirow{2}{*}{\multicolumn{3}{|c|}{ Prostrate }} & \multirow{2}{*}{\multicolumn{3}{|c|}{ Erect }} & \multirow{2}{*}{\multicolumn{3}{|c|}{ Statistical significance }} \\
\hline & & & & & & & & & \\
\hline & Grass & Herb & Legume & Grass & Herb & Legume & Form & Type & Form x Type \\
\hline Item & & & & & & & & $P$-value & \\
\hline Intake rate $(\mathrm{g} \mathrm{DM} / \mathrm{min})^{1}$ & 3.9 & 7.2 & 7.0 & 5.4 & 5.4 & 5.4 & 0.03 & 0.0001 & 0.0001 \\
\hline Bite mass (mg/bite) & 108 & 220 & 200 & 189 & 252 & 188 & 0.006 & 0.0001 & 0.009 \\
\hline Biting rate (bites/min) & 42 & 37 & 39 & 37 & 31 & 32 & 0.0001 & 0.006 & NS $^{2}$ \\
\hline Bite depth (cm) & 4.1 & 3.6 & 5.0 & 7.5 & 7.8 & 7.1 & 0.0001 & NS & 0.0001 \\
\hline Bite area $\left(\mathrm{cm}^{2}\right)$ & 11.5 & 13.3 & 19.5 & 21.4 & 20.1 & 18.1 & 0.0001 & 0.02 & 0.0002 \\
\hline Bite volume $\left(\mathrm{cm}^{3}\right)$ & 55.8 & 54.4 & 116.8 & 217.9 & 213.5 & 178.5 & 0.0001 & NS & 0.0003 \\
\hline
\end{tabular}

1 Intake rate is based on the mean of individual bite mass and biting rate and does equate to the product of mean bite mass and biting rate ; ${ }^{2} \mathrm{NS}=$ not significant 